\title{
Randomization of Genes by PCR Mutagenesis
}

\author{
R. Craig Cadwell and Gerald F. Joyce
}

Departments of Chemistry and Molecular Biology, The Scripps Research Institute, La Jolla, California 92037

A modified polymerase chain reaction (PCR) was developed to introduce random point mutations into cloned genes. The modifications were made to decrease the fidelity of Taq polymerase during DNA synthesis without significantly decreasing the level of amplification achieved in the PCR. The resulting PCR products can be cloned to produce random mutant libraries or transcribed directly if a $T 7$ promoter is incorporated within the appropriate PCR primer. We used this method to mutagenize the gene that encodes the Tetrahymena ribozyme with a mutation rate of $0.66 \% \pm 0.13 \%$ (95\% C.I.) per position per PCR, as determined by sequence analysis. There are no strong preferences with respect to the type of base substitution. The number of mutations per DNA sequence follows a Poisson distribution and the mutations are randomly distributed throughout the amplified sequence. he technology of in vitro mutagenesis allows one to probe structurally and functionally important regions within cloned genes. Random mutagenesis, coupled with a screening method, is especially useful when functionally significant positions are not well known. Several methods have been utilized to introduce random mutations into cloned genes, including chemical mutagenesis, ${ }^{(1-4)}$ incorporation of nucleotide analogues, ${ }^{(5-7)}$ passage through bacteria that contain mutator genes, ${ }^{(8)}$ incorporation of randomized synthetic oligonucleotides, ${ }^{(9-20)}$ and inaccurate copying by a polymerase. ${ }^{(21-28)}$ We find inaccurate copying by a polymerase to be the most attractive because of its simplicity and versatility.

The fidelity of several DNA polymerases has been measured, including the Klenow fragment of Escherichia coli DNA polymerase I, ${ }^{(29)}$ T4 DNA polymerase, ${ }^{(21)}$ modified T7 DNA polymerase (Sequenase), ${ }^{(30)}$ Taq DNA polymerase, ${ }^{(31-35)}$ and Thermococcus litoralis (Vent) DNA polymerase. ${ }^{(36)}$ The fidelity of Taq polymerase is the lowest and, when coupled to the amplificative power of the PCR, ${ }^{(37,38)}$ makes Taq the best candidate for an in vitro mutagenesis procedure. The error rate of Taq is $0.001-0.02 \%$ per nucleotide per pass of the polymerase, depending upon reaction conditions. ${ }^{(33,34)}$ For most purposes, this is insufficient to mutagenize a gene. Thus, modifications of either the reaction conditions or the polymerase itself are needed to achieve a substantial reduction of fidelity.

There is a paper in the literature describing a random mutagenesis procedure based on modification of the PCR. ${ }^{(25)}$ The fidelity of the PCR was reduced by increasing the concentration of $\mathrm{MgCl}_{2}$, adding $\mathrm{MnCl}_{2}$ to the reaction mixture, increasing and unbalancing the concentrations of the four dNTPs, increasing the concentration of Taq polymerase, and increasing the extension time. Under the most error-prone condition, the claimed error rate is $2 \%$ per position per PCR, with an equal number of transitions and transversions. ${ }^{(25)} \mathrm{We}$ tested the most error-prone condition reported by Leung et al. and obtained a mutation rate of $1.37 \% \pm 0.29 \%(95 \%$ C.I.). However, there were approximately three times as many transitions as transversions, with a strong bias toward $A \rightarrow G$ and $T \rightarrow C$ transitions. This result prompted us to develop a new PCR mutagenesis protocol that does not have strong mutational bias and provides an overall error rate of $0.66 \% \pm 0.13 \%$ (95\% C.I.).

\section{MATERIALS AND METHODS}

\section{Materials}

AmpliTaq DNA polymerase was purchased from Cetus; EcoRI, HindIII, and T4 polynucleotide kinase were from New England Biolabs; and T4 DNA ligase, MoMLV reverse transcriptase, and Sequenase (version $2.0 \mathrm{kit}$ ) were from United States Biochemical. Buffered solutions of dNTPs and NTPs were purchased from Pharmacia. PCR primers, 5'-CTGCAGAATTCTAATACGACTCACTATAGGAGGGAAAAGTTATCAGGC-3' and $\mathbf{5}^{\prime}$ CCAAGCTTGATCTCGAGTACTCCAAAACTAATC-3', and sequencing primers compatible with the pUC 18 plasmid, 5'GTAAAACGACGGCCAGT- $3^{\prime}$, and $5^{\prime}$ CATGATTACGAATTCTA-3', were purchased from Operon Technologies and purified by polyacrylamide gel electrophoresis and subsequent Sephadex chromatography. $\left[{ }^{35} \mathrm{~S}\right]-(\alpha$-thio)-dATP (1000 $\mathrm{Ci} / \mathrm{mmole}$ ) was from Amersham. $E$. coli strain $\mathrm{DH} 5 \alpha-\mathrm{F}^{\prime(39)}$ was obtained from 
BRL. Parent plasmid pT7L-2 $1^{(40)}$ was provided by T.R. Cech and cloning plasmid pUC $18(\Delta \mathrm{P} 2 / \Delta \mathrm{P} 5)^{(41)}$ was provided by D.J. Decker. T7 RNA polymerase ${ }^{(42)}$ was prepared according to a modification of a procedure originally developed for SP6 RNA polymerase. ${ }^{(43)}$

\section{Preparation of Wild-type cDNA}

Plasmid pT7L-21 was transcribed as previously described ${ }^{(41)}$ and the resulting RNA was purified by polyacrylamide gel electrophoresis and subsequent Sephadex chromatography. The purified RNA was used to synthesize cDNA autocatalytically by an isothermal amplification procedure. ${ }^{(44,45)}$ The amplification mixture contained 50 fmoles of RNA, 100 pmoles (each) PCR primers (see Materials), $10 \mathrm{~mm} \mathrm{MgCl}_{2}, 80 \mathrm{~mm} \mathrm{KOAc,} 5 \mathrm{~mm}$ dithiothreitol, $50 \mathrm{~mm}$ Tris $\cdot \mathrm{HCl}(\mathrm{pH} 7.5)$, 2 mм (each) NTPs, 0.2 mm (each) dNTPs, 125 units of Mo-MLV reverse transcriptase, and 500 units of T7 RNA polymerase in a $100-\mu l$ volume, which was incubated at $37^{\circ} \mathrm{C}$ for $3 \mathrm{hr}$. The RNA was digested by alkaline hydrolysis and the cDNA was purified by electrophoresis in a $5 \%$ polyacrylamide $/ 8 \mathrm{~m}$ urea gel and subsequent affinity chromatography on Du Pont Nensorb. The yield of cDNA was quantitated spectrophotometrically.

\section{Polymerase Chain Reaction}

The standard reaction condition was compared to four mutagenic reaction conditions. All reaction mixtures contained 20 fmoles cDNA, 30 pmoles (each) PCR primers (see Materials), 50 $\mathrm{mM} \mathrm{KCl}, 10 \mathrm{~mm}$ Tris. $\mathrm{HCl}(\mathrm{pH} \mathrm{8.3)}$, and $0.01 \%$ gelatin in a $100-\mu$ l volume, which was cycled in an Ericomp thermal cycler for 30 cycles of $94^{\circ} \mathrm{C}$ for $1 \mathrm{~min}, 45^{\circ} \mathrm{C}$ for $1 \mathrm{~min}$, and $72^{\circ} \mathrm{C}$ for $1 \mathrm{~min}$. We did not employ a hot start procedure and did not carry out a prolonged extension reaction at the end of the last cycle. In addition to the above components, the standard reaction mixture contained $1.5 \mathrm{mM} \mathrm{MgCl}_{2}$, 2.5 units of Taq polymerase, and $0.2 \mathrm{~mm}$ (each) dNTPs; the mutagenic reaction mixtures contained $7 \mathrm{mM} \mathrm{MgCl}, 0.5 \mathrm{~mm}$ $\mathrm{MnCl}_{2}, 5$ units of Taq polymerase, and varying concentrations of the four dNTPs. $\mathrm{MnCl}_{2}$ must be added just prior to enzyme to prevent precipitation. PCR products were purified by chloroform/ isoamyl alcohol extraction and ethanol precipitation. Yields were estimated by running a small aliquot of the reaction mixture on a $2 \%$ agarose gel and visualizing the ethidium bromide-stained products in comparison to known amounts of DNA.

\section{Cloning of PCR Products}

To facilitate restriction digestion, $2.5 \mu \mathrm{g}$ of PCR product DNA was concatenated in a concerted kination / ligation reaction, as previously described. ${ }^{(46)}$ The enzymes were heat-inactivated, the buffer was adjusted to $50 \mathrm{~mm} \mathrm{NaCl}$, and the DNA was digested with EcoRI and HindIII. The pUC18 ( $\Delta \mathrm{P} 2 / \Delta \mathrm{P} 5)$ plasmid was similarly digested with EcoRI and HindIII and purified in 1\% low-meltingpoint agarose gel. This vector contains two large deletions in the ribozyme gene that were PCR amplified, making it easy to distinguish vector religation products from vector that has incorporated the PCR fragment. The restriction-digested PCR fragment was incorporated into the target vector by ligation within lowmelting point agarose. ${ }^{(47)}$ The resulting plasmid DNA was used to transform competent DH5 $\alpha-\mathrm{F}^{\prime}$ cells, ${ }^{(48)}$ which were grown on ampicillin-containing plates. Individual colonies were chosen at random and grown overnight in LB media. DNA was prepared by a boiling lysis miniprep protocol ${ }^{(49)}$ and screened for the presence of insert by restriction digestion.

\section{DNA Sequencing}

DNAs were sequenced by the chain-termination method ${ }^{(50)}$ using reciprocal primers that flank the cloned insert (see Materials). Sequencing reactions utilized modified T7 DNA polymerase (Sequenase 2.0, USB) and $\left[{ }^{35} \mathrm{~S}\right]-(\alpha$-thio)-dATP and were analyzed by electrophoresis in a $6 \%$ polyacrylamide $/ 8 \mathrm{~m}$ urea sequencing gel. The 353 nucleotide positions that lie between the two sequencing primers were used for statistical analysis.

\section{RESULTS}

We first compared the standard PCR to the mutagenic PCR described by Leung and co-workers. ${ }^{(25)}$ The Leung protocol employs several modifications relative to the standard PCR that might be considered mutagenic, including: (1) increased concentration of Taq polymerase; (2) increased extension time; (3) increased concentration of $\mathrm{MgCl}_{2} ;$ (4) addition of $0.5 \mathrm{mM} \mathrm{MnCl}_{2}$ to the reaction mixture; and (5) increased (1 $\mathrm{mM}$ ) concentration of dGTP, dCTP, and dTTP together with standard $(0.2 \mathrm{mM})$ concentration of dATP. The last two modifications are expected to have the greatest impact on error rate.

With the standard PCR, we obtained only 1 mutation in 3177 nucleotides that were sequenced. Thus, based on a onetailed $t$-test, the error rate is $<0.14 \%$ per position (95\% C.I.). This error rate reflects both mutations that occur during the PCR and mutations that occur during our preparative procedure. It is consistent with published values obtained under similar reaction conditions ${ }^{(34,38)}$ and establishes a baseline for the present study. To obtain a more precise estimate of the error rate for the standard PCR, one must either sequence a very large number of nucleotides or, as has been done in the past, turn to in vivo selection markers to screen a large population of DNA sequences for the presence of a single mutation. In general, direct sequencing is impractical unless the mutation rate is above $0.2 \%$ per position per PCR.

We tested a mutagenic PCR based on Leung's conditions and obtained an overall mutation rate of $1.37 \% \pm 0.29 \%$ per position per PCR (95\% C.I.; $n=$ $6001)$. This is in reasonable agreement with the published value of $2 \%$. $^{(25)}$ However, there was a substantial excess of $A$ $\rightarrow \mathrm{G}$ and $\mathrm{T} \rightarrow \mathrm{C}$ mutations, resulting in strong GC sequence bias (Table 1). The probability of mutation at an A or T position was $2.14 \% \pm 0.51 \%$, while the probability of mutation at a $\mathrm{G}$ or $\mathrm{C}$ position was only $0.37 \% \pm 0.24 \%(95 \%$ C.I.). This bias can be understood in terms of the competition between dATP and dGTP for base-pairing at T positions along a DNA template (see Discussion). There may be special circumstances in which it is desirable to apply GC pressure while mutagenizing a gene. However, we sought to address the broader need for a mutagenesis technique that does not impose sequence bias.

Previous studies concerning the effect of unbalanced concentrations of the four dNTPs on the fidelity of T4 DNA polymerase showed that the mutation rate could be increased only by increasing the $\mathrm{dGTP} / \mathrm{dATP}$ ratio. ${ }^{(21)}$ Predictably, this condition leads to an excess of $\mathrm{A} \rightarrow$ $\mathrm{G}$ and $\mathrm{T} \rightarrow \mathrm{C}$ changes. The same limita- 
TABLE 1 Error Rate of the PCR Under Various Mutagenic Reaction Conditions ${ }^{\mathrm{a}}$

\begin{tabular}{|c|c|c|c|c|c|}
\hline $\begin{array}{l}\text { [dGTP] } \\
\mathrm{mm}\end{array}$ & $\begin{array}{l}\text { [dATP] } \\
\mathrm{mM}\end{array}$ & $\begin{array}{l}\text { Nucleotides } \\
\text { sequenced }\end{array}$ & $\begin{array}{l}\text { Mutation rate } \\
\text { ( } 95 \% \text { C.I.) }\end{array}$ & $\frac{\mathrm{AT} \rightarrow \mathrm{GC}}{\mathrm{GC} \rightarrow \mathrm{AT}}$ & $\frac{\text { Transitions }}{\text { Transversions }}$ \\
\hline 1.0 & 0.2 & 6,001 & $1.37 \pm 0.29 \%$ & 10 & 2.7 \\
\hline 0.2 & 0.2 & 16,591 & $0.66 \pm 0.13 \%$ & 1 & 0.8 \\
\hline 0.2 & 1.0 & 1,765 & $0.85 \pm 0.43 \%$ & 2 & 0.4 \\
\hline 0.4 & 0.2 & 3,177 & $0.72 \pm 0.29 \%$ & 4 & 3.2 \\
\hline
\end{tabular}

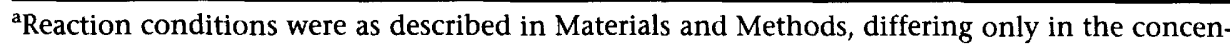
tration of dGTP and dATP. Mutation rate refers to the mean number of mutations per base pair per PCR (30 cycles). Frequencies of AT $\rightarrow \mathrm{GC}$ and GC $\rightarrow \mathrm{AT}$ mutations are corrected for base composition of the mutated gene.

tion might be expected to apply to other DNA polymerases. However, Taq polymerase, which operates at higher temperature and has lower inherent fidelity compared to T4 DNA polymerase, turns out to be vulnerable to a variety of alterations in dNTP concentrations.

Our preferred reaction condition for PCR mutagenesis employs $0.2 \mathrm{~mm}$ dGTP, $0.2 \mathrm{~mm}$ dATP, $1 \mathrm{~mm} \mathrm{dCTP}$, and $1 \mathrm{~mm}$ dTTP, but is otherwise identical to our formulation of the Leung condition described above. The preferred condition results in an overall mutation rate of $0.66 \% \pm 0.13 \%$ per position per PCR (95\% C.I.; $n=16,591)$ and is free from GC or AT bias (Table 1). This data reflects the sum of two independent experiments, which were carried out using different stock solutions and analyzed by separate cloning and sequencing procedures. The two independent mutation rates were $0.64 \%(n=9884)$ and $0.69 \%$ $(n=6707)$, which do not differ significantly. Individual rates for various types of mutations of the form $\mathrm{N} \rightarrow \mathrm{X}$ and $\mathrm{X} \rightarrow$ $\mathrm{N}(\mathrm{N}=\mathrm{G}, \mathrm{A}, \mathrm{C}, \mathrm{T} ; \mathrm{X} \neq \mathrm{N})$ were tabulated for the two independent samples and, in all cases, found not to differ significantly at even the $90 \%$ confidence level. Thus, data from the two independent samples was pooled.

The preferred reaction condition results in no strong mutational bias (Fig. 1). There is a modest preference for $T \rightarrow$ $X$ changes $(X \neq T)$ and $X \rightarrow A$ changes $(X$ $\neq A$ ), both significant at the $99 \%$ confidence level. All other $\mathrm{N} \rightarrow \mathrm{X}$ and $\mathrm{X} \rightarrow \mathrm{N}$ changes cannot be said to differ at even the $90 \%$ confidence level. The frequency of insertions and deletions is $<0.03 \%$ and $<0.05 \%$, respectively (one-tailed test, $95 \%$ C.I.).

Two other reaction conditions were tested in an attempt to obtain a higher overall mutation rate while maintaining low mutational bias. The PCR was carried out in the presence of $0.2 \mathrm{mM}$ dGTP, $1 \mathrm{~mm}$ dATP, $1 \mathrm{~mm}$ dCTP, and $1 \mathrm{mM}$ dTTP, under reaction conditions otherwise identical to those above. This resulted in an error rate of $0.85 \% \pm 0.43 \%$ per position per PCR (95\% C.I.; $n=1,765$ ) (Table 1), but with strong bias in favor of $A \rightarrow X$ $(X \neq A)$ and $X \rightarrow T$ changes $(X \neq T)$. Finally, we tested a "compromise" con-
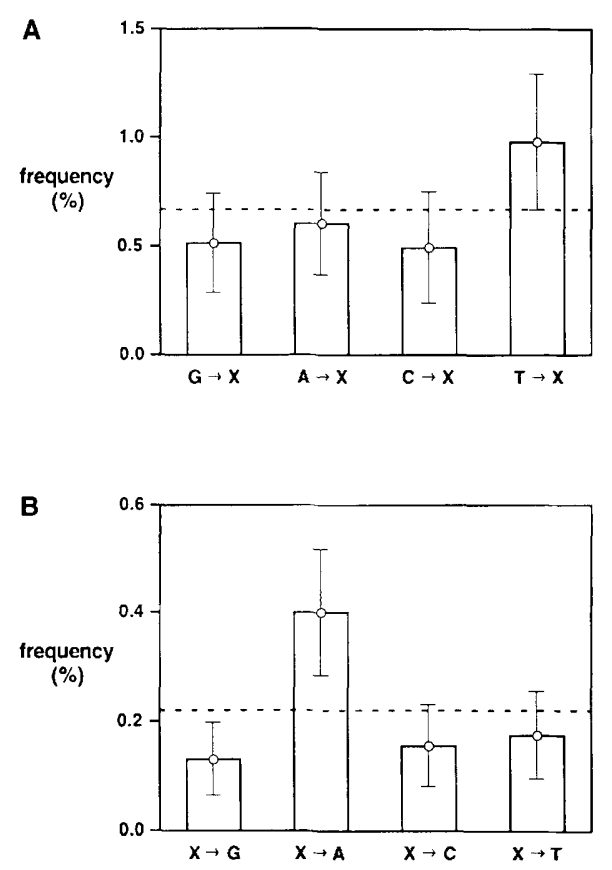

FIGURE 1 Frequency of various types of mutations under the preferred reaction condition for PCR mutagenesis. $(A)$ Mutations of the form $\mathrm{N} \rightarrow \mathrm{X} ;(B)$, Mutations of the form $\mathrm{X}$ $\rightarrow \mathrm{N} ;(\mathrm{N}=\mathrm{G}, \mathrm{A}, \mathrm{C}, \mathrm{T} ; \mathrm{X} \neq \mathrm{N})$. Frequencies refer to the mean number of mutations per base pair per PCR (30 cycles), corrected for base composition of the mutagenized gene. Error bars correspond to $95 \%$ confidence interval. Dashed horizontal line indicates expected value based on an overall error rate of $0.66 \%$ per position per PCR.

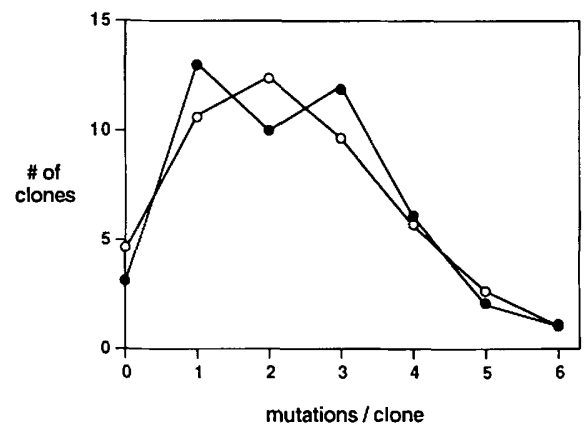

FICURE 2 Comparison of observed number of mutations per DNA sequence (O) with expected values based on a Poisson distribution (O). A $G$-test for goodness of fit gave $G=$ 3.26; when compared with the chi-square distribution ( 6 d.f.) this indicates no significant difference between observed and expected values.

dition using $0.4 \mathrm{mM}$ dGTP, $0.2 \mathrm{~mm}$ dATP, $1 \mathrm{~mm}$ dCTP, and $1 \mathrm{~mm}$ dTTP. This resulted in an error rate of $0.72 \% \pm 0.29 \%$ per position per PCR (95\% C.I.; $n=$ 3,530 ) (Table 1), but with strong bias in favor of $A \rightarrow X$ changes $(X \neq A)$.

Returning to the preferred reaction condition, we tested whether there were any mutational "hotspots" or clustering of mutations within the DNA sequence. The number of mutations per DNA sequence (109 mutations; 47 sequences) follows a Poisson distribution (Fig. 2). The mutations are randomly distributed throughout the amplified sequence, with no obvious nearest-neighbor effects (Fig. 3). The yield of DNA in the mutagenic PCR does not differ significantly from the yield in the standard PCR, as judged by agarose gel electrophoresis in the presence of ethidium bromide.

\section{DISCUSSION}

Much has been made of the importance of maximizing the fidelity of the PCR. ${ }^{(30,33,34)}$ Indeed, if the PCR is being used as a preparative procedure prior to subcloning, a low mutation rate is desirable. However, there are instances in which a low-fidelity polymerization reaction would be useful, provided that it does not result in significant mutational bias.

Recently, a number of in vitro selective amplification techniques have been developed that depend on generation of an initial population of random variants. ${ }^{(51-64)}$ Normally this is accomplished by preparing degenerate oligode- 
$\stackrel{\cdots \text { CAGGCATGCACCTGGTAGCTAGTCTTIAACCAATAGATT }}{\downarrow}$

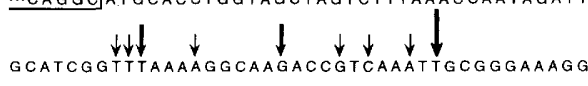
$\underset{\text { GGTCAACAGCCGITCAGTACCAAGTCTCAGGGGAACTTG }}{\downarrow}$ AGATGGCCTGGAAGGGTATGGTAAAAGCTGACGGACAT $\underset{\text { GGTCCTAACCACGCAGCCAAGTCCTAAGTCACAGATCTTC }}{\downarrow} \downarrow$

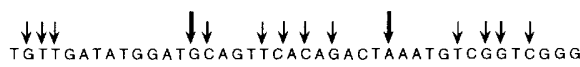
$\underset{\text { GAAGATGTATTCTTCTCATAAGATATAGTCGGACCTCTCCTT }}{\downarrow}$ AATGGGAGCTAGCGGATGAAGTATGCAACACTGGAGCCG

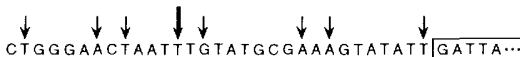

FIGURE 3 Distribution of mutations within the gene that was amplified. (Short arrow) One occurrence; (medium-length arrow) two occurrences; (long arrow) three occurrences; no position was mutated more than three times. The DNA strand having the same sense as the RNA transcript is shown. Boxed regions correspond to primer binding sites.

oxynucleotides on an automated DNA synthesizer using nucleoside 3 '-phosphoramidite solutions that have been doped with a small percentage of each of the three incorrect monomers. ${ }^{(13,16,17,20)}$ The degenerate oligodeoxynucleotides are made doublestranded and ligated into the target gene. This method is time consuming and expensive compared to a mutagenic PCR. Furthermore, it does not allow one to remutagenize those individuals that have been selected from the initial mutant population. The ability to iterate the mutation process while carrying out repeated rounds of selective amplification greatly augments in vitro selection, in effect converting it to an in vitro evolution procedure. ${ }^{(65)}$

More generally, PCR mutagenesis can be used to randomize any cloned gene for the purpose of generating mutant libraries that can be screened for the expression of some desirable phenotype. If the promoter sequence for T7 RNA polymerase is included in the appropriate PCR primer, then the PCR products can be transcribed directly to produce a population of mutant RNAs. If these RNAs contain an AUG start codon and maintain proper codon usage, then they can be translated in vitro to produce a corresponding population of mutant proteins.

In this study, we analyzed and subse- quently modified the PCR mutagenesis procedure of Leung and co-workers ${ }^{(25)}$ to obtain a method for gene randomization that does not impose strong sequence bias. The Leung protocol, which employs increased concentrations of dGTP, dCTP, and dTTP relative to dATP results in a substantial excess of $A \rightarrow G$ and $T \rightarrow$ $\mathrm{C}$ changes. This is likely due to formation of G-T "wobble" pairs between incoming dGTPs and $T$ positions along the DNA template, favored by the increased dGTP : dATP ratio. Misincorporation of $G$ opposite $T$ accounts for the $A \rightarrow G$ changes, and copying of a misincorporated $G$ during the next pass of the polymerase accounts for the $\mathrm{T} \rightarrow \mathrm{C}$ changes. Maintaining relatively low concentrations of both dATP and dGTP would make such events less favorable. Mass action would then be expected to favor the four transversion mutations. However, we found transitions and transversions to occur in a ratio of $0.75: 1$, which does not differ significantly from the unbiased value of $0.5: 1$ (90\% confidence level). This suggests that there are other mutagenic forces operating in the PCR.

Addition of $0.5 \mathrm{mM} \mathrm{MnCl}_{2}$ to the reaction mixture is expected to have a significant mutagenic effect. $\mathrm{MnCl}_{2}$ is known to be mutagenic for a variety of DNA polymerases ${ }^{(23)}$ and data of Leung and co-workers suggest that this is the case for Taq polymerase as well. ${ }^{(25)} \mathrm{We}$ have made no attempt to cooptimize the concentrations of $\mathrm{MnCl}_{2}$ and the four dNTPs to achieve maximal error rate while maintaining minimal sequence bias. An obvious way to increase the overall error rate of the PCR would be to carry out more reaction cycles, although this increases the risk of obtaining PCR artifacts. ${ }^{(66)}$ Similarly one could carry out two consecutive PCRs, perhaps purifying the products of the first reaction by gel electrophoresis before proceeding with the second reaction. A more subtle way to increase the error rate of the PCR is to increase the concentration of Taq polymerase or to increase the extension time within each reaction cycle. These changes are expected to promote chain extension beyond positions of base mismatch. ${ }^{(67)}$ Finally, it has been shown that the error rate of the PCR is enhanced by increasing the concentration of $\mathrm{MgCl}_{2}{ }^{(30,33)}$ which presumably stabilizes noncomplementary pairs, and by increasing the $\mathrm{pH},{ }^{(30,33)}$ which may have an effect on the polymerase itself.
The PCR mutagenesis procedure described in this study should be sufficient for most gene randomization purposes. We encourage others to seek further modifications of the reaction conditions that would result in a higher error rate without producing significant sequence bias. The types of manipulations discussed above would be a reasonable place to start. Ultimately, though perhaps only after the three-dimensional structure of a thermostable DNA polymerase is available, it may be possible to modify the polymerase itself to obtain a low-fidelity enzyme.

\section{ACKNOWLEDGMENTS}

We are grateful to Steven Reed for helpful suggestions. This work was supported by NASA grant NAGW-1671 and NIH grant AI30882.

\section{REFERENCES}

1. Chu, C.-T., D.S. Parris, R.A.F. Dixon, F.E Farber, and P.A. Schaffer. 1979. Hydroxylamine mutagenesis of HSV DNA and DNA fragments: Introduction of mutations into selected regions of the viral genome. Virology 98: 168-181.

2. Shortle, D. and D. Botstein. 1983. Directed mutagenesis with sodium bisulfite. Methods Enzymol. 100: 457-468.

3. Myers, R.M., L.S. Lerman, and T. Maniatis. 1985. A general method for saturation mutagenesis of cloned DNA fragments. Science 229: 242-247.

4. Diaz, J.-J., D.D. Rhoads, and D.J. Roufa. 1991. PCR-mediated chemical mutagenesis of cloned duplex DNAs. BioTechniques 11: $204-211$

5. Flavell, R.A., D.L. Sabo, E.F. Bandle, and C. Weissmann. 1974. Site-directed mutagenesis: Generation of an extracistronic mutation in bacteriophage Q $\beta$ RNA. I. Mol. Biol. 89: 255-272.

6. Mueller, W., H. Weber, F. Meyer, and C. Weissmann. 1978. Site-directed mutagenesis in DNA: Generation of point mutations in cloned $\beta$-globin complementary DNA at the positions corresponding to amino acids 121 to 123 . J. Mol. Biol. 124: 343-358.

7. Mott, J.E., J. van Arsdell, and T. Platt. 1984. Targeted mutagenesis in vitro: lac repressor mutations generated using AMV reverse transcriptase and dBrUTP. Nucleic Acids Res. 12: 4139-4152.

8. Cox, E.C. 1976. Bacterial mutator genes and the control of spontaneous mutation. Annu. Rev. Genet. 10: 135-156.

9. Matteucci, M.D. and H.L. Heyneker. 1983. Targeted random mutagenesis: The use of 
ambiguously synthesized oligonucleotides to mutagenize sequences immediately $5^{\prime}$ of an ATG initiation codon. $\mathrm{Nu}$ cleic Acids Res. 11: 3113-3121.

10. Hui, A., J. Hayflick, K. Dinkelspiel, and H.A. de Boer. 1984. Mutagenesis of the three bases preceding the start codon of the $\beta$-galactosidase mRNA and its effect on translation in Escherichia coli. EMBO J. 3: 623-629.

11. Dreher, T.W., J.J. Bujarski, and T.C. Hall. 1984. Mutant viral RNAs synthesized in vitro show altered aminoacylation and replicase activities. Nature 311: 171-175.

12. Wells, J.A., M. Vasser, and D.B. Powers. 1985. Cassette mutagenesis: An efficient method for generation of multiple mutations at defined sites. Gene 34: 315-323.

13. McNeil, J.B. and M. Smith. 1985. Saccharomyces cerevisiae $\mathrm{CYC} 1$ mRNA 5'-end positioning: Analysis by in vitro mutagenesis using synthetic duplexes with random mismatch base pairs. Mol. Cell. Biol. 5: 3545-3551.

14. Oliphant, A.R., A.L. Nussbaum, and K. Struhl. 1986. Cloning of random-sequence oligodeoxynucleotides. Gene 44: 177-183.

15. Horwitz, M.S.Z. and L.A. Loeb. 1986. Promoters selected from random DNA sequences. Proc. Natl. Acad. Sci. 83: 74057409.

16. Hutchison, C.A., S.K. Nordeen, K. Vogt, and M.H. Edgell. 1986. A complete library of point substitution mutations in the glucocorticoid response element of mouse mammary tumor virus. Proc. Natl. Acad. Sci. 83: 710-714.

17. Derbyshire, K.M., J.J. Salvo, and N.D.F. Grindley. 1986. A simple and efficient procedure for saturation mutagenesis using mixed oligodeoxynucleotides. Gene 46: $145-152$.

18. Ner, S.S., D.B. Goodin, and M. Smith. 1988. A simple and efficient procedure for generating random point mutations and for codon replacements using mixed oligonucleotides. DNA 7: 127-134.

19. Reidhaar-Olson, J.F. and R.T. Sauer. 1988. Combinatorial cassette mutagenesis as a probe of the information content of protein sequences. Science 241: 53-57.

20. Hermes, J.D., S.M. Parekh, S.C. Blacklow, H. Köster, and J.R. Knowles. 1989. A reliable method for random mutagenesis: the generation of mutant libraries using spiked oligodeoxynucleotide primers. Gene 84: 143-151.

21. Sinha, N.K. and M.D. Haimes. 1981. Molecular mechanisms of substitution mutagenesis: an experimental test of the Watson-Crick and Topal-Fresco models of base mispairings. J. Biol. Chem. 256: 10671-10683.

22. Zakour, R.A. and L.A. Loeb. 1982. Site-specific mutagenesis by error-directed DNA synthesis. Nature 295: 708-710.
23. Beckman, R.A., A.S. Mildvan, and L.A. Loeb. 1985. On the fidelity of DNA replication: Manganese mutagenesis in vitro. Biochemistry 24: 5810-5817.

24. Lehtovaara, P.M., A.K. Koivula, J. Bamford, and J.K.C. Knowles. 1988. A new method for random mutagenesis of complete genes: Enzymatic generation of mutant libraries in vitro. Prot. Eng. 2: 63-68.

25. Leung, D.W., E. Chen, and D.V. Goeddel. 1989. A method for random mutagenesis of a defined DNA segment using a modified polymerase chain reaction. Technique 1: 11-15.

26. Holm, L., A.K. Koivula, P.M. Lehtovaara, A. Hemminki, and J.K.C. Knowles. 1990. Random mutagenesis used to probe the structure and function of Bacillus stearothermophilus. Prot. Eng. 3: 181-191.

27. Liao, X. and J.A. Wise. 1990. A simple high-efficiency method for random mutagenesis of cloned genes using forced nucleotide misincorporation. Gene 88: 107-111.

28. Zhou, Y., X. Zhang, and R.H. Ebright. 1991. Random mutagenesis of gene-sized DNA molecules by use of PCR with Taq DNA polymerase. Nucleic Acids Res. 19: 6052.

29. Keohavong, P. and W.G. Thilly. 1989. Fidelity of DNA polymerases in DNA amplification. Proc. Natl. Acad. Sci. 86: 92539257.

30. Ling, L.L., P. Keohavong, C. Dias, and W.G. Thilly. 1991. Optimization of the polymerase chain reaction with regard to fidelity: Modified T7, Taq, and Vent polymerases. PCR Methods Applic. 1: 63-69.

31. Tindall, K.R. and T.A. Kunkel. 1988. Fidelity of DNA Synthesis by the Thermus aquaticus DNA polymerase. Biochemistry 27: 6008-6013.

32. Ennis, P.D., J. Zemmour, R.D. Salter, and P. Parham. 1990. Rapid Cloning of HLAA,B CDNA by using the polymerase chain reaction: Frequency and nature of errors produced in amplification. Proc. Natl. Acad. Sci. 87: 2833-2837.

33. Eckert, K.A. and T.A. Kunkel. 1990. High fidelity DNA synthesis by the Thermus aquaticus DNA polymerase. Nucleic Acids Res. 18: 3739-3744.

34. Eckert, K.A. and T.A. Kunkel. 1991. DNA polymerase fidelity and the polymerase chain reaction. PCR Methods Applic. 1: 1724.

35. Chen, J., A. Sahota, P.J. Stambrook, and J.A. Tischfield. 1991. Polymerase chain reaction amplification and sequence analysis of human mutant adenine phosphoribosyltransferase genes: The nature and frequency of errors caused by Taq DNA polymerase. Mutat. Res. 249: 169-176.

36. Mattila, P., J. Korpela, T. Tenkanen, and K. Pitknen. 1991. Fidelity of DNA synthesis by the Thermococcus litoralis DNA polymerase-an extremely heat stable enzyme with proofreading activity. Nucleic Acids Res. 19: 4967-4973.

37. Saiki, R.K., S. Scharf, F. Faloona, K.B. Mullis, G.T. Horn, H.A. Erlich, and N. Arnheim. 1985. Enzymatic amplification of $\beta$-globin genomic sequences and restriction site analysis for diagnosis of sickle cell anemia. Science 230: 1350-1354.

38. Saiki, R.K., D.H. Gelfand, S. Stoffel, S.J. Scharf, R. Higuchi, G.T. Horn, K.B. Mullis, and H.A. Erlich. 1988. Primer-directed enzymatic amplificiation of DNA with a thermostable DNA polymerase. Science 239: 487-491.

39. Hanahan, D. 1983. Studies on transformation of Escherichia coli with plasmids. J. Mol. Biol. 166: 557-580.

40.Zaug, A.J., C.A. Grosshans, and T.R. Cech. 1988. Sequence-specific endoribonuclease activity of the Tetrahymena ribozyme: Enhanced cleavage of certain oligonucleotide substrates that form mismatched ribozyme-substrate complexes. Biochemistry 27: 8924-8931.

41. Beaudry, A.A. and G.F. Joyce. 1990. Minimum secondary structure requirements for catalytic activity of a self-splicing group I intron. Biochemistry 29: 65346539.

42. Studier, F.W. and B.A. Moffatt. 1986. Use of bacteriophage T7 RNA polymerase to direct selective high-level expression of cloned genes. J. Mol. Biol. 189: 113-130.

43. Butler, E.T. and M.J. Chamberlin. 1982. Bacteriophage SP6-specific RNA polymerase. I. Isolation and characterization of the enzyme. J. Biol. Chem. 257: 57725778.

44. Guatelli, J.C., K.M. Whitfield, D.Y. Kwoh, K.J. Barringer, D.D. Richman, and T.R. Gingeras. 1990. Isothermal, in vitro amplification of nucleic acids by a multienzyme reaction modeled after retroviral replication. Proc. Natl. Acad. Sci. 87: 1874-1878.

45. Joyce, G.F. 1992. Selective amplification techniques for optimization of ribozyme function. In Antisense RNA and DNA (ed. J.A.H. Murray), pp. 353-372. Wiley-Liss, New York.

46. Kaufman, D.L. and G.A. Evans. 1990. Restriction endonuclease cleavage at the termini of PCR products. BioTechniques 9: 304-306.

47. Maniatis, T., E.F. Fritsch, and J. Sambrook. 1989. Molecular cloning: A laboratory manual, pp. 1.72-1.73. Cold Spring Harbor Press, Cold Spring Harbor, New York.

48. Hanahan, D. 1985. Techniques for transformation of $E$. coli. In DNA cloning: $A$ practical approach (ed. D.M. Glover), pp. 109-135. IRL Press, Oxford.

49. Holmes, D.S. and M. Quigley. 1981. A rapid boiling method for the preparation of bacterial plasmids. Anal. Biochem. 114: 193-197.

50. Sanger, F., S. Nicklen, and A.R. Coulson. 
1977. DNA sequencing with chain-terminating inhibitors. Proc. Natl. Acad. Sci. 74: $5463-5467$.

51. Joyce, G.F. 1989. Amplification, mutation and selection of catalytic RNA. Gene 82: 83-87.

52. Robertson, D.L. and G.F. Joyce. 1990 . Selection in vitro of an RNA enzyme that specifically cleaves single-stranded DNA. Nature 344: 467-468.

53. Scott, J.K. and G.P. Smith. 1990. Searching for peptide ligands with an epitope library. Science 249: 386-390.

54. Devlin, J.J., L.C. Panganiban, and P.E. Devlin. 1990. Random peptide libraries: A source of specific protein binding molecules. Science 249: 404-406.

55. Cwirla, S.E., E.A. Peters, R.W. Barrett, and W.J. Dower. 1990. Peptides on phage: A vast library of peptides for identifying ligands. Proc. Natl. Acad. Sci. 87: 63786382.

56. Tuerk, C. and L. Gold. 1990. Systematic evolution of ligands by exponential enrichment: RNA ligands to bacteriophage T4 DNA polymerase. Science 249: 505510.

57. Ellington, A.D. and J.W. Szostak. 1990. In vitro selection of RNA molecules that bind specific ligands. Nature 346: 818-822.

58. McCafferty, J., A.D. Griffiths, G. Winter, and D.J. Chiswell. 1990. Phage antibodies: Filamentous phage displaying antibody variable domains. Nature 348: 552554.

59. Clackson, T., H.R. Hoogenboom, A.D. Griffiths, and G. Winter. 1991. Making antibody fragments using phage display libraries. Nature 352: 624-628.

60. Barbas, C.F., A.S. Kang, R.A. Lerner, and S.J. Benkovic. 1991. Assembly of combinatorial antibody libraries on phage surfaces: The gene III site. Proc. Natl. Acad. Sci. 88: 7978-7982.

61. Pei, D., H.D. Ulrich, and P.G. Schultz. 1991. A combinatorial approach toward DNA recognition. Science 253: 14081411.

62. Bartel, D.P., M.L. Zapp, M.R. Green, and J.W. Szostak. 1991. HIV-1 Rev regulation involves recognition of non-WatsonCrick base pairs in viral RNA. Cell 67: 529-536.

63. Lowman, H.B., S.H. Bass, N. Simpson, and J.A. Wells. 1991. Selecting high-affinity binding proteins by monovalent phage display. Biochemistry 30: 10832-10838.

64. Bock, L.C., L.C. Griffin, J.A. Latham, E.H. Vermaas, and J.J. Toole. 1992. Selection of single-stranded DNA molecules that bind and inhibit human thrombin. Nature 355: 564-566.

65. Beaudry, A.A. and G.F. Joyce. 1992. Directed evolution of an RNA enzyme. Science (in press).

66. Innis, M.A. and D.H. Gelfand. 1990. Optimization of PCRs. In PCR protocols: $A$ guide to methods and applications (eds. M.A. Innis, D.H. Gelfand, J.J. Sninsky, and T.J. White), pp. 3-12. Academic Press, San Diego.

67. Gelfand, D.H. and T.J. White. 1990. Thermostable DNA polymerases. In PCR protocols: A guide to methods and applications (eds. M.A. Innis, D.H. Gelfand, J.J. Sninsky, and T.J. White), pp. 129-141. Academic Press, San Diego.

Received April 24, 1992; accepted in revised form June 8, 1992. 


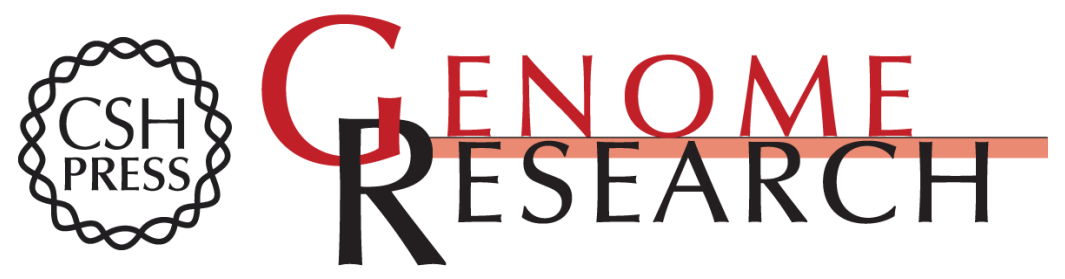

\section{Randomization of genes by PCR mutagenesis.}

R C Cadwell and G F Joyce

Genome Res. 1992 2: 28-33

Access the most recent version at doi:10.1101/gr.2.1.28

References This article cites 61 articles, 19 of which can be accessed free at:

http://genome.cshlp.org/content/2/1/28.full.html\#ref-list-1

\section{License}

Email Alerting Receive free email alerts when new articles cite this article - sign up in the box at the Service top right corner of the article or click here.

\section{Affordable, Accurate Sequencing.}

To subscribe to Genome Research go to:

https://genome.cshlp.org/subscriptions 